\title{
Reconceptualización de la noción transculturación en La música en Cuba de Alejo Carpentier
}

\author{
Bernat Garí Barceló ${ }^{1}$
}

Resumen. El desinterés que los ensayos musicales de Carpentier han suscitado entre los integrantes del aparato crítico ha revertido en una desatención sistemática de su musicología y el examen de su impronta en su novelística. El propósito de este artículo pasa, primeramente, por ubicar el ensayo musical carpenteriano en el conjunto de la producción ensayística del autor, y por deslindar, en segundo término, las funciones que este desempeña en tanto poética. En tercer término, se van a sintetizar las tesis que vertebran La música en Cuba, para constatar cómo en dicho texto se recategoriza la noción orticiana de transculturación, y para corroborar, finalmente, su recodificación en la novelística del autor.

Palabras clave: Carpentier; Ortiz; ensayo; musicología; transculturación.

\section{[en] The reconceptualization of the notion of transculturation in La música en Cuba by Alejo Carpentier}

\begin{abstract}
The disinterest in Carpentier's musical essays demonstrated by critics has resulted in a systematic neglect of his musicology and the evaluation of its effect on his novels. The purpose of this article is, firstly, to identify the Carpenterian musical essay from the wider body of the author's essays and secondly, to define the poetic functions that it carried out. Thirdly, the theory underpinning $L a$ música en Cuba will be summarised to demonstrate how the Ortizian notion of transculturation is recategorized in said text. Finally, evidence will be provided to illustrate the recoding of the text in the author's oeuvre.
\end{abstract}

Keywords: Carpentier; Ortiz; essay; musicology; transculturation.

Sumario. 1. Introducción. 2. La ensayística de Alejo Carpentier: aspectos, cronología y ramificaciones. 3. De la balcanización a la integración: la reconceptualización de la noción transculturación en La música en cuba de Alejo Carpentier. 4. A modo de Síntesis.

Cómo citar: Garí, B. (2019) Reconceptualización de la noción de transculturación en La música en Cuca de Alejo Carpentier, en Revista de Anales de Literatura Hispanoamericana 48, 485-500.

1 Centro Universitario Internacional de Barcelona/Universitat de Barcelona, Barcelona. España.

E-mail: bernatgari@hotmail.com 


\section{Introducción}

Los músicos son terriblemente irrazonables. Siempre quieren que uno sea totalmente mudo en el preciso momento que uno desea ser completamente sordo.

Oscar Wilde

La novelística de Carpentier, desde El reino de este mundo (1949) en adelante, se halla en íntima sintonía con el ideario del autor en tanto musicólogo. Alumbrar las ideas constitutivas del ensayo carpenteriano permite rehacer los itinerarios del autor, reseguir sus pasos, sus lecturas, los bosquejos e intuiciones que le llevaron a desertar de una poética preeminentemente regionalista y situarse en el centro de la problemática interacción entre lo nacional y lo supranacional. Para Carpentier, el fracaso del Grupo Minorista y del regionalismo literario residía en su incapacidad por expresar el ser americano. Según el autor, la reelaboración especular del mundo y la predilección por elementos culturalmente periféricos contribuyeron en oscurecer el ethos americano, en escamotear la esencia de un sujeto ubicado en el epicentro de un mestizaje en el que se entrelazan culturas, almas y cuerpos. El regionalismo constituía el "paso necesario para comprender mejor ciertos factores poéticos, musicales, étnicos y sociales, que habían contribuido a dar una fisonomía propia a lo criollo" (Carpentier, 2004: 307), pero habría que ir un paso más allá para materializar en la novela un ascenso de lo local a lo universal que desvelase las complejidades del ser americano y sus principios constitutivos. Esta idea brevemente bosquejada toma forma en los ensayos La música en Cuba (1946) y Tristán e Isolda en Tierra Firme (1949) y será el caldo de cultivo de la narrativa del autor desde la publicación de El reino de este mundo (1949).

La hipótesis no es original y ha sido inventariada reiteradamente desde distintos enfoques por los integrantes del aparato crítico, si bien nadie ha abordado de raíz el estudio exhaustivo del ensayismo carpenteriano y, menos aún, su examen contrastivo con la novelística del autor. Tempranamente, ya en 1970, Alexis Márquez Rodríguez, en La obra narrativa de Alejo Carpentier, auguró la importancia del "copiosísimo material periodístico producido por él [Carpentier] durante catorce años de permanencia en Venezuela [...] porque fue precisamente en ese período cuando se escribieron todos los cuentos y novelas estudiados por nosotros" (1970: 10). Análogamente, Müller Bergh, en 1972, confirió al periodismo crítico carpenteriano y su ensayismo musical una función instructiva que dotaría al futuro novelista de un asombroso acervo de recursos y materiales (1972: 32). Tres años más tarde, Esther P. Mocega indicó que, al efecto de los preparativos de la revolución haitiana, ficcionalizada en la novela El reino de este mundo, resultan de especial relevancia las ideas que el autor despliega en $L a$ música en Cuba (1975: 105). En Música y épica en la novela de Alejo Carpentier, Leonardo Acosta ratifica que en las más importantes creaciones literarias del autor "reaparecen temas y personajes que ya conocíamos a través de la lectura de $L a$ música en Cuba" (1981: 25). En 1985, Velayos Zurdo, a tenor de unas 
disquisiciones sobre La consagración de la primavera, anotó que "dicha novela no solo refleja el sentir del autor en esta época, sino que recoge también numerosos datos concretos, tomados [...] de las crónicas escritas por aquellos años para Social y Carteles" (1985: 72). Y, así, de modo reiterado, hasta artículos y estudios de mayor actualidad: en 2003, por ejemplo, Armando Cristóbal insiste en que "resulta interesante el que sean estas reflexiones, aparecidas en sus crónicas periodísticas, las que se transparenten en el angustioso itinerario que recorre Vera [en $L a$ consagración de la primavera]" (2003: 168); o Pogolotti, en El ojo de Alejo, indica cómo el análisis de La música en Cuba y "los vínculos de trabajo con los compositores Roldán y Caturla conducen a una concepción de cultura que rompe los tradicionales linderos de las bellas artes. El mestizaje cultural se descubre en los términos concretos" (2007: 86-87). Finalmente, en un rastreo que podría dilatarse ad infinitum, Cancio apuntala la necesidad de un estudio omniabarcador de la obra periodística carpenteriana, "vista en estrecha relación con la concepción narrativa del escritor" (2010: 16).

El propósito de este artículo pasa por corroborar las intuiciones del aparato crítico y descubrir unos textos que han suscitado un interés exiguo. A tales efectos, en primer lugar, voy a situar el ensayo musical carpenteriano en el conjunto de la producción ensayística del autor, para deslindar, a renglón seguido, las funciones que dichos textos desempeñan en tanto poética. La vastedad del corpus ensayístico de Carpentier y su intermitencia en la cronología productiva del autor hacen necesaria una sistematización de dichos textos con fines operativos y metodológicos, labor que emprenderé en la sección que sigue. En el tercer apartado, me ocuparé de sintetizar las ideas vertebradoras del ensayo La música en Cuba para ratificar su impronta, su influjo sutil, en la novelística del autor. La musicología de Carpentier es una poética en potencia cuya materialización concluye en la diégesis, en un itinerario que se eleva de la música a la palabra. No se trata tanto, como veremos, de una reelaboración especular con incursiones al ensayo o autoplagios intencionales, ni de una hibridación desde la que fracturar el espacio genérico, sino de una recodificación narratológica imbuida de la reflexión que Carpentier despliega en su ensayismo.

\section{La ensayística de Alejo Carpentier: aspectos, cronología y ramificaciones}

Adorno, en un escrito que se ha hecho célebre, expresaba que

es inherente a la forma del ensayo su propia relativización: el ensayo tiene que estructurarse como si pudiera suspenderse en cualquier momento. El ensayo piensa discontinuamente, como la realidad es discontinua, y encuentra su unidad a través de las rupturas, no intentando taparlas [...]. La discontinuidad es esencial al ensayo, su cosa es siempre un conflicto detenido (1962: 27).

Esa naturaleza truncada o sectorial constitutiva, también, del ensayo carpenteriano se resuelve en la realización narrativa del autor, colmada de las ideas, bosquejos e intuiciones que fueron previamente delineados en su reflexión de cariz ensayístico. 
Es revelador que Carpentier dedique tantas páginas a reflexionar sobre la música vernácula: nos dice de su interés por lo musical, nos dice del influjo que este ejerce sobre su poética. El ensayo musicológico del autor satura su novelística de sucesos, personajes, anécdotas y cavilaciones de toda índole, pero no solo eso: hay una reflexión de fondo que atomiza la concepción novelística del primer Carpentier -el acérrimo militante del Grupo Minorista- y la transfigura. Su relevancia va más allá de meros juegos transtextuales y autoplagios, pero para entenderlo, valdría la pena ubicar el ensayo carpenteriano en el conjunto de su producción.

La ensayística de Alejo Carpentier despliega tres reflexiones de distinta índole que se interseccionan y complementan entre sí: el ensayo musical, acervo de la ontología carpenteriana desde los años 40 y caldo de cultivo de su novelística; el ensayo literario, tardío cronológicamente, que sintetiza los principios constitutivos del credo autoral; y el ensayo geográfico, que opera como intertexto subyacente en la codificación paisajística de novelas como Los pasos perdidos o El siglo de las luces. Existe, asimismo, un amplio arco de artículos y reseñas de temática cinematográfica, si bien dichas piezas son un rara avis en el conjunto de la producción carpenteriana y trascienden los propósitos de mi empresa.

La ensayística musicológica de Carpentier abarca cuatro textos cenitales: el tratado La música en Cuba -el texto madre--, resultado de una labor intensiva de síntesis, búsqueda e investigación sobre las fuentes estructuradoras de la música cubana; los ensayos breves Tristán e Isolda en Tierra Firme (1949) y Del folklorismo musical (1964), que destacan por su recategorización de la noción Weltliteratur, literatura mundial, acuñada por Goethe, y su proyección en el contexto latinoamericano, y, finalmente, el escrito América Latina en la confluencia de coordenadas históricas y su repercusión en la música (1981), epítome en el que cristalizan las ideas centrales de la musicología carpenteriana ${ }^{2}$.

En su ensayismo musical, Carpentier postula que el sustrato metafísico, el arjé, del ser americano es el mestizaje. Según el autor, América es esencialmente mestiza y, por ende, barroca, pues en todo abrazo de culturas se engendra un barroquismo: la palabra legada por los españoles debe ensancharse en aras de expresar los estratos que se funden en el curso de la transculturación. El barroco es el utensilio con el que tapar los boquetes de una lengua incapaz de materializar la grandeza de América. Este es el sustento teórico que justifica esa pirotecnia verbal a la que nos tiene acostumbrados el autor. Aduzco, entonces, que la musicología carpenteriana puede entenderse como una ontología, una reconfiguración fisionómica de la imagen de América y del ser americano. El qué, la pregunta sobre la sustancia, es la cuestión epicéntrica de la musicología del autor.

El ensayo literario engloba textos tipológicamente dispares (preámbulos, reseñas, opúsculos, conferencias, clases dictadas, etc.), entre los que destacan el

\footnotetext{
${ }^{2}$ Existen varios textos de temática similar que desarrollan, con mayor o menor fortuna, las reflexiones de dichos ensayos, a saber, "Panorama de la música cubana" (1944), publicado en Conservatorio, adelanto de lo que el autor dará a conocer con mayor extensión y generosidad en La música en Cuba; Breve historia de la música cubana (1954), anejo de la enciclopedia Libro de Cuba, que sintetiza las líneas centrales de La música en Cuba, la conferencia "Nuestro acento a la música contemporánea universal" (1966), el texto Música y emoción, publicado en 1972, y el libreto para el documental Sobre la música cubana (1973). Katia Chornik, en su tesis The Role of Music in Selected Novels and Associated Writings of Alejo Carpentier: Primeval Expression, Structural Analogies and Performance, edita el texto de Carpentier Los orígenes de la música y la música primitiva destinado a convertirse en una conferencia que debía ser emitida por radio.
} 
prólogo a El reino de este mundo (1949), que dicotomiza lo real maravilloso, privativo de América Latina, del surrealismo y la literatura fantástica europeos; los escritos breves "Problemática de la actual novela latinoamericana", "Literatura y conciencia política en América Latina" y "De lo real maravilloso americano" que integran el volumen Tientos y diferencias (1964); el discurso "Conciencia e identidad de América", dictado en el Aula Magna de la Universidad Central de Venezuela el 15 de mayo de 1975, la conferencia Un camino de medio siglo, en la Sala de Conciertos de dicha universidad el 20 de mayo de 1975, la lección impartida en el Ateneo de Caracas el 22 de mayo de 1975, Lo barroco y lo real maravilloso, y, finalmente, la conferencia Problemática del tiempo y el idioma en la moderna novela latinoamericana, oficiada en el Aula Magna de la Universidad Central de Venezuela en mayo de 1975. Dichos textos fueron compendiados en el volumen de ensayos Razón de ser (1976) y en "Conciencia e identidad en América" $(1981)^{3}$ y conforman la epistemología del autor: una teoría programática sobre cómo aprehender América y en función de qué coyunturas, y, especialmente, sobre cómo plasmarla. El peso del ensayo literario, por ende, recae en el cómo, es decir, en la cuestión sobre la nomenclatura.

Finalmente, el ensayo geográfico abarca tres textos nucleares. Destaco, en primer término, el ensayo La ciudad de las columnas (1970), con fotografías de Pablo Gaspariani, que circunscribe la ciudad de La Habana en el planisferio de las grandes urbes, confiriéndole sustento histórico; en segundo lugar, la obra paisajística Visión de América, florilegio de artículos divulgados previamente en Carteles ${ }^{4}$; y, finalmente, el ensayo Bajo el signo de Cibeles que incluye textos análogos publicados en medios como Carteles y Social, que reproducen las vivencias del autor bajo el fuego en el Segundo Congreso Internacional de Escritores para la Defensa de la Cultura celebrado entre el 4 y el 18 de julio de 1937. El propósito del autor, en ese escrito último, es el de hacernos vivir "la emoción profunda de un viaje a España [...]; trataré de haceros sentir el crescendo de esa emoción, que se amplifica como un regulador de partitura musical, hasta alcanzar el fortissimo gigantesco, inhumano y tan humano de Madrid" (1979: 134). El ensayo geográfico, pese a su exquisitez explicativa, no opera únicamente en términos de sublimación del paisaje americano, sino que arma una teoría holística, una geo-antropología, destinada a solventar la tensión que resulta de la dramática interacción entre el sujeto y el medio que lo produce. El fundamento explicativo del hombre es multifactorial, pero está en íntima sintonía con el hábitat. Visto así, el ensayismo geográfico de Carpentier desempeña una función geo-antropológica que responde al dónde y a los efectos que de él se derivan.

${ }^{3}$ Existen otros ensayos cuya temática se solapa con la de las conferencias indicadas, a saber, la ponencia realizada en el seno de la Universidad de Yale en el año 1979, "La novela latinoamericana en vísperas de un nuevo siglo", así como la versión traducida de una intervención, originalmente, en francés pronunciada en 1967 en los Rencontres Internationales de Ginebra titulada Papel social del novelista. También destaca el discurso en la ceremonia de entrega del Premio Miguel de Cervantes el 4 de abril de 1978. Tales escritos son accesibles en La novela latinoamericana en vísperas de un nuevo siglo y otros ensayos (1981).

${ }^{4}$ Los escritos agrupados en Visión de América incluyen "La Gran Sabana: Mundo del Génesis", publicado en Carteles el 25 de enero de 1948, "El salto del ángel en el reino de las aguas", en Carteles, fechado el 22 de febrero de 1948, y "La Biblia y la ojiva en el ámbito del Roraima", difundido en Carteles el 28 de mayo de 1948. Visión de América también se ha editado como texto único, intercalado entre los escritos de La novela latinoamericana en vísperas de un nuevo siglo y otros ensayos (1981), y en la edición de Seix Barral Visión de América (1999). 
Al amparo de estos presupuestos, es posible inventariar los ensayos constitutivos de la poética autoral según criterios teleológicos y de contenido, tal y como se aprecia en la tabla que sigue (fig. I).

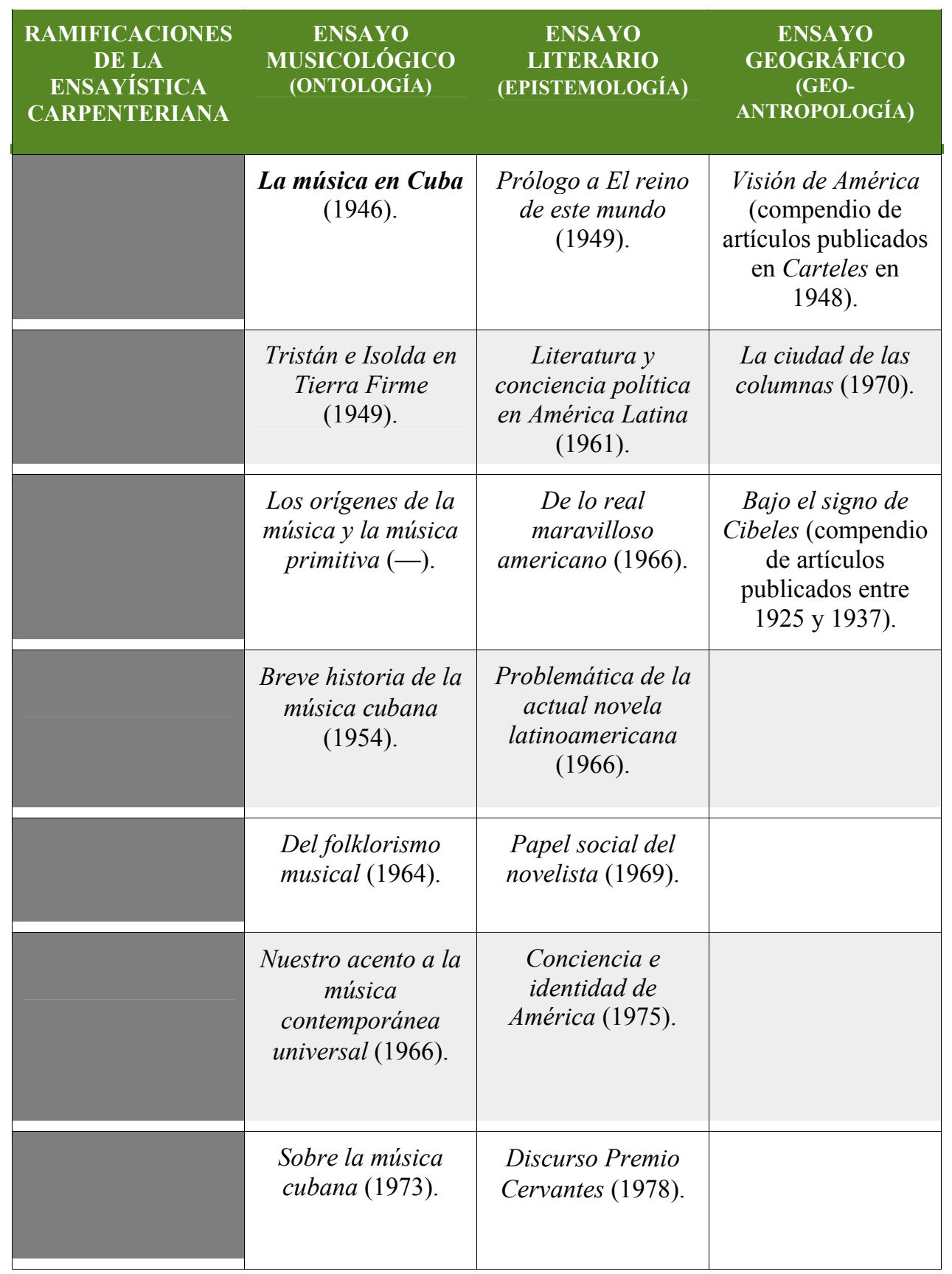




\begin{tabular}{|c|c|c|c|}
\hline $\begin{array}{c}\text { RAMIFICACIONES } \\
\text { DE LA } \\
\begin{array}{c}\text { ENSAYÍSTICA } \\
\text { CARPENTERIANA }\end{array}\end{array}$ & $\begin{array}{c}\text { ENSAYO } \\
\text { MUSICOLÓGICO } \\
\text { (ONTOLOGÍ) }\end{array}$ & $\begin{array}{c}\text { ENSAYO } \\
\text { LITERARIO } \\
\text { (EPISTEMOLOGÍA) }\end{array}$ & $\begin{array}{c}\text { ENSAYO } \\
\text { GEORÁFICO } \\
\text { (GEO- }\end{array}$ \\
\hline & $\begin{array}{c}\text { América Latina en } \\
\text { Su música (1977). }\end{array}$ & $\begin{array}{c}\text { Afirmación literaria } \\
\text { americanista } \\
\text { (1978). }\end{array}$ & \\
\hline & & $\begin{array}{c}\text { La novela } \\
\text { latinoamericana en } \\
\text { visperas de un } \\
\text { nuevo siglo }(1979) .\end{array}$ & \\
\hline
\end{tabular}

Fig. I

Las disquisiciones que Carpentier despliega en su ensayo musical serán particularmente ilustrativas de su deserción del Grupo Minorista, fundamentarán su rechazo a la tendencia folklorizante de la novela regionalista y se convertirán en el anclaje de una nueva narrativa que toma forma en El reino de este mundo y que culmina en las realizaciones centrales del programa carpenteriano.

\section{De la balcanización a la integración: la reconceptualización de la noción transculturación en La música en cuba de Alejo Carpentier Pietro}

El negro se escurría, inventando, entre las notas impresas. El blanco se atenía a la solfa. Alejo Carpentier

Para Carpentier, el redescubrimiento de la música vernácula adquiere, en el ensayo La música en Cuba, visos de epifanía. Al regresar de Haití, en 1944, Carpentier pasó por México, donde el Fondo de Cultura Económica le encomendaría una historia de la música cubana destinada a inscribirse en el marco de una enciclopedia de carácter global (Chao 1998: 162). El autor se enfrasca, entonces, en una exhaustiva labor de búsqueda, síntesis y compilación con la que armar un texto total que abarcase los periodos estructuradores de la música cubana. El resultado informaría sobre el ciclo embrionario y formativo de la música culta en Cuba, a través de una comparsa inagotable de profesores, músicos y compositores, entre los que destacan Esteban Salas, Espadero, Ignacio Cervantes, Amadeo Roldán y Alejandro García Caturla; pero, más relevante que eso, el ensayo cambiaría la escritura del autor y su concepción de la novela como artefacto indiciario de lo americano.

Tras el barniz de esa pretendida objetividad, soterrado, subyace en La música en Cuba un programa ideológico que aborda la cuestión sobre el ser americano. 
Carpentier sabe que en toda producción artística se entrecruzan la historicidad específica y el sueño de pertenencia y, por tanto, la exégesis musicológica es indisociable del empaque sociopolítico. Bajo el examen del hecho sonoro el autor codifica un mensaje oculto, a modo de elipsis, que está sin estar, y que participa de otras disciplinas como la antropología cultural y la historiografía. En la configuración de la música cubana se materializa un proceso de transculturación, sometido a los avatares del colonialismo español y a una dialéctica en la que concurren amo y esclavo, en la que se imbrican melos y ritmo como categorías antagónicas de lo apolíneo y lo dionisíaco. Carpentier lo corrobora desde las primeras páginas del ensayo madre: "en todos los momentos de su historia, la isla de Cuba elaboró un folklore sonoro de una sorprendente vitalidad, recibiendo, mezclando y transformando aportaciones diversas, que acabaron por dar origen a géneros fuertemente caracterizados" (2004: 10). Más adelante, en el capítulo I, aduce que "si algo, en la música cubana, está siempre fuera de todo misterio, es su vinculación directa con algunas de sus raíces originales, aun en los casos en que esas raíces se entretejen al punto de constituir un organismo nuevo" (2004: 31).

El término transculturación designa un proceso que participa de la alteridad -el prefijo latino trans significa "al otro lado de, "más allá de"- y en el que una sustancia A se problematiza en el contacto con B de lo que resulta C. Fernando Ortiz lo diría con suma exquisitez: "en todo abrazo de culturas sucede lo que en la cópula genética de los individuos: la criatura siempre tiene algo de ambos progenitores, pero también siempre es distinta de cada uno de los dos" (2002: 142). En el marco de esta retórica, a Carpentier se le revela meridianamente la relevancia del acervo musical europeo en la constitución de la música culta cubana. Para él es plausible que el aporte europeo se haya adueñado de los elementos diferenciales de la cultura africana, o sea, el potencial estructurador que la melos adquiere en la amalgama de la transculturación es, a todos los efectos, preponderante. Evidentemente, la condición de posibilidad de la transculturación es oscilante y asimétrica por cuanto la cultura fuente permuta en su imbricación con otra, se diluye o, a veces, incluso, claudica. El resultado hace indiscernible los partícipes en la unidad, pero el rastreo del proceso da pistas sobre la genealogía del acabado y, sobre todo, sobre los beneficiarios del acoplamiento. Existe, en definitiva, cierto grado de supeditación que Ortiz escamoteó, o no quiso ver, en su repudio parcial de nociones tales como aculturación o deculturación.

Jorge Castellanos e Isabel Castellanos, en la estela de la dialéctica hegeliana, postulan que la aculturación musical del Caribe se consuma en tres ciclos funcionales, no exentos de los habituales desmanes que la lógica imperialista de Occidente impone en sus empresas de sometimiento, dominio y asimilación:

1. Aprendizaje obligado de la cultura del amo, sustituyendo con ella parte de la suya;

2. Adquisición de elementos de otras culturas africanas, a través de su convivencia con esclavos procedentes de regiones de África distintas a la suya; y 3. Traspaso de parte de su acervo cultural a la cultura de sus amos.

(Castellanos, 1988: 56-57). 
Como vemos, el diálogo es asimétrico y, fatalmente, en el producto reverberan las relaciones que se urdieron entre opresores y oprimidos. Los dos primeros puntos pueden interpretarse categorialmente como aculturación y neoculturación: en un primer momento, los nativos y los esclavos se sometieron a una cultura virtualmente superior a expensas de la propia; en un segundo momento, la interacción casual con otros sistemas sígnicos ensanchó lo propio y lo perturbó. En el tercer punto, aquí sí, opera lato sensu lo que Ortiz acuñó como transculturación: la revalorización de lo propio en el reconocimiento de lo ajeno, asimilándolo, de lo que se infiere el principio sustancial del ser americano. Todorov expresó, en esa línea, que el descubrimiento del otro revierte siempre en un reconocimiento de lo que somos, en un itinerario de fuera a dentro que lleva de la problemática relación con la alteridad a una reconceptualización del yo. En esa lógica dialéctica, sin duda, todos se roban un poco, pero, no nos engañemos, unos más que otros. La simbiosis que acaece en Cuba desde el siglo XVI entre culturas desiguales obedece a leyes y relaciones desiguales, que alteran, por tanto, el acabado del producto. Este será el hallazgo más importante de Carpentier en el ensayo madre.

Con la noción transculturación, Ortiz había incrustado en el centro de su sistema el ideal martiano de la integración y conciliación entre etnias -la célebre concordia discors en términos aristotélicos-, principio nuclear del programa ideológico del Grupo Minorista entre los que militaba el joven Carpentier junto a autores como Agustín Acosta, Mañach, Nicolás Guillén o Marinello". Villanueva aduce que "la orientación de Carpentier será monotemática, a partir del encuentro con Ortiz y el grupo de la Sociedad del Folklore" (2005: 119). Tanto es así que la huella del pensamiento orticiano es, perfectamente, rastreable en la primera novela del joven Carpentier, ¡Écue-Yamba-Ó!, texto que el autor repudiaría en sus años de madurez y en el que se materializan los principios rectores de la novela regionalista: la saturación del discurso literario con elementos culturalmente periféricos, la institución de un arte vernáculo con el que encauzar una revaluación de las formas obsoletas de realismo o la recodificación de la propuesta vanguardista y su adecuación al contexto americano, entre otros. Carpentier expresa que esa primera novela es "un intento fallido por el abuso de metáforas, de símiles mecánicos, de imágenes de un aborrecible gusto futurista y por esa falsa concepción de lo nacional que teníamos entonces" (Leante 1970: 22).

Nótese que entre la publicación de iÉcue-Yamba-Ó!, en 1933, y El reino de este mundo, en 1949, dista un periodo tremebundo de dieciséis años. Ese lapso de tiempo corresponde al ciclo formativo del escritor. A lo largo de esos años, Carpentier se dedica, tal como lo confiesa, "a leer todo lo que podía sobre América, desde las Cartas de Cristóbal Colón, pasando por el Inca Garcilaso [...]. Por espacio de ocho años creo que no hice otra cosa que leer textos americanos" (Leante, 1970: 21). La escritura de los ensayos La música en Cuba y Tristán e Isolda en Tierra Firme se ubica en esos años de ajetreo. En ellos cristalizaría una

Huelga recordar que la noción transculturación aparece por primera vez en 1940 en la obra de Ortiz Contrapunteo cubano del tabaco y el azúcar como síntesis de los procesos de aculturación y deculturación que desde el siglo XVI se vienen fraguando en territorio cubano. Con todo, la labor de Ortiz con la fundación de la Sociedad del Folklore Cubano, en 1924, y con la publicación de obras como Los cabildos afrocubanos (1921) o Glosario de afronegrismos (1924) fue determinante en la constitución del Grupo Minorista. 
reconfiguración de la fisionomía americana lo que los convierte en la ontología del autor por cuanto legan un nuevo modo de pensar América y de expresarla.

La labor intensiva de búsqueda, síntesis e investigación a la que se somete el autor culminan en la confección de un texto total, La música en Cuba, en el que, difusamente, el autor recategoriza la noción transculturación como definitoria de una dialéctica asimétrica entre la cultura dominante y la subalterna, y en la que el hecho sonoro no está exento de las contingencias clasistas y pugnas de poder que han aquejado desde tiempos inmemoriales la vieja Europa. Los bosquejos y tentativas del autor conducen a una relectura crítica de la noción orticiana, y prefiguran, con varias décadas de anticipación, la problematización del concepto por los integrantes del aparato crítico. Recordemos que Cornejo Polar, análogamente, constataba cómo la transculturación

implicaría a la larga la construcción de un nivel sincrético que finalmente insume en una unidad más o menos desproblematizada (pese a que el proceso que la produce pueda ser muy conflictivo) dos o más lenguas, conciencias étnicas, códigos, estéticos, experiencias históricas, etc. Añado que el espacio donde se configuraría la síntesis es el de la cultura hegemónica; que a veces se obviaría la asimetría social de los contactos que le dan origen; y, finalmente, que dejaría al margen los discursos que no han incidido en el sistema de la literatura 'ilustrada (1994: 36).

Lo que está en juego en la recategorización del concepto es un asunto poco menos que teleológico: por un lado, de él dependen el sustrato metafísico de América, esto es, la ontología del autor, y, por el otro, la optimización de los recursos y herramientas que permitan el ensamblaje entre el ser y la palabra, es decir, la epistemología del autor y su nomenclatura, su logos. No se trata solo, tal como lo veo, de un debate inocuo sobre el potencial explicativo del concepto, sino de la constatación de las contradicciones intrínsecas de la modernidad latinoamericana: la consabida dicotomización entre americanistas y universalistas.

En un artículo de generosa extensión, "Panorama de la música en Cuba", que el autor publica en Conservatorio en el año 1944, en donde vehicula algunas de las tesis centrales que subyacen en La música en Cuba, Carpentier reseña la febril polémica mantenida entre guajiristas y afrocubanistas a tenor de la genealogía de algunos ritmos acentuales idiosincrásicos de la música cubana. Los primeros postulaban que el principio diferenciador de la música cubana era de ascendencia americana, indígena; frente a los afrocubanistas que resaltan la impronta indiscutible del ethos africano en las sonatas, preludios, fugas y otras estructuras afines de origen europeo. Confiesa el autor, en un fragmento en el que se evidencia su distanciamiento de la ortodoxia minorista, que

nuestro ingenuo grito de guerra era: “¡Abajo la lira, viva el bongó!”. La lira era la ópera, la canción, el italianismo, la languidez. El bongó era, para nosotros, símbolo de lo rítmico, lo percusivo, lo neto, lo nervioso. Claro está -y puedo confesarlo ahora- [y no antes, en plena prédica minorista] que no nos ilusionábamos demasiado acerca de las posibilidades de lo afrocubano. Sabíamos que un folklore, por rico que sea, no puede alimentar eternamente a un músico 
que habrá de situarse, tarde o temprano, ante los problemas eternos de la música universal (1994: 158).

Mismamente, en el opúsculo "Variaciones sobre un tema cubano", publicado en Crónica en 1951, el autor expresa que el Modernismo decimonónico se fundó, entre otros aspectos, en un virulento rechazo de los rasgos específicamente vernáculos y en una revisitación de la Weltliteratur acuñada por Goethe, lo que propició una revalorización del folklore afrocubano en la década de los veinte desde distintas esferas hasta el punto de que "ahora en reacción contra ese espíritu discriminatorio, se iba hacia lo negro con un entusiasmo casi excesivo, hallando en su ámbito ciertos valores que se preferían a otros" (Carpentier 1994: 169-170). El cosmopolitismo decimonónico, consumados los procesos de independencia a lo largo del siglo XIX, se amparaba en el afán de propulsar las letras americanas al planisferio de los universales, lo que revirtió, según Carpentier, en una lectura hipercrítica de las fuentes vernáculas y folklóricas. De la tesis cosmopolita pregonada por el modernismo finisecular deriva la antítesis archifolklorizante de la novela regionalista y, específicamente, del Grupo Minorista, de lo que se deduce la síntesis de la poética carpenteriana que toma forma, años después, en La música en Cuba.

El matiz diferencial que dicotomiza el programa de Carpentier del de un modernista como Darío se halla, por un lado, en el modo de revaluar lo propio: en Carpentier, la materia prima de América reside en sus mitos, sus ritmos, en el acento diferenciador que el negro imprime en la música blanca; en un discurso fruto de amalgamas raciales y entrecruzamientos culturales. En Darío, en cambio, la factura de los materiales es de importación, y estos deben ser recodificados sublimados- por una aristocracia de eruditos e intelectuales. Por otro lado, Carpentier, a diferencia de Darío, se halla en la estela de la concepción cívica del poeta, como Bello y Martí, permeables al traqueteo sociopolítico y militantes en una literatura al servicio de la acción revolucionaria. Pese a todo, las propuestas de Darío y Carpentier se solapan en el propósito de fondo: la búsqueda de una manera nueva de pensar y plasmar América para elevarla al panteón de los universales.

Carpentier reescribe la historia de la música cubana con ese objetivo en el punto de mira. De ahí que opere desde una perspectiva desmitificadora del aporte afrocubano, recategorizando la noción transculturación, y admitiendo, además, la relevancia del acervo musical europeo en materia logística: instrumentos, maestros, orquestas, conservatorios y un sistema productivo de probada eficiencia que llevaba, desde Bach, varios decenios consolidado. El blanco aporta el sistema, que mediatiza la transculturación; el negro, el matiz acentual que engendra las variantes en relación a la cultura fuente. El afrocubano, se arguye en La música en Cuba, imprime en la melos "un acento, una vitalidad, un algo no escrito, que levantaba" (2004: 141). Años después, en América Latina en la confluencia de coordenadas históricas y su repercusión en la música el autor define la rítmica negrista como una inflexión particular, un acento privativo, o un "lirismo venidos de adentro", como factores mucho más valiosos que "el material melódico en sí” (1981: 175). El negro se escurre entre la solfa y su deje interpretativo permuta las formas musicales del blanco, lo que lo convierte en el agente del cambio. 
Resulta ilustrativo, no obstante, que el paratexto de La música en Cuba incorpore un título a todas luces omniabarcador, y que tras un escudriño que se extiende a lo largo de centenares de páginas, Carpentier dedique apenas una sucinta sección al folklore afrocubano. Una simple ojeada al índice general debería despertar recelos: en el programa del autor se vislumbra una voluntad de desacralización de lo afrocubano que, en el cómputo general de la transculturación, solo opera en tanto elemento diferenciador. No sin resentimiento, años después, en el prólogo a La música afrocubana, Ortiz destacaría que "el estudio de la música afrocubana es, pues, muy difícil y está por hacer [...] el reciente libro de Carpentier sobre La música en Cuba es una acertada apreciación de sus perspectivas históricas y globales" (1974: 169). Ortiz fue uno de los primeros en convencerse de la deriva ideológica del ya no tan joven Carpentier. Al leer La música en Cuba se cercioró de que había perdido un prosélito por cuanto el autor había subordinado la relevancia del hecho musical africano al aporte europeo en materia melódica, armónica e instrumental.

En carta a Rodríguez Feo, a finales de 1949, Carpentier expresa que "el espectáculo de mi generación (la de 1927) me irrita bastante" (1989:17). No es imprudente, por tanto, consignar que de ¡Écue-Yamba-Ó! a El reino de este mundo se fragua un proceso de desminorización que cortocircuita el ideario regionalista del autor, cuyo sustento teórico puede rastrearse en La música en Cuba y en la nueva musicología carpenteriana. Wilfredo Cancio va un poco más allá y habla de una origenización de la prosa autoral al constatar cómo Carpentier hallaría "en el taller renacentista del grupo Orígenes una respuesta válida para sustentar un sentido de lo cubano que su generación no había podido resolver sin concesiones al costumbrismo folclórico, y en lo cual va implícita una autocrítica (Ecué Yamba O)" (2010: 252). De hecho, de entre integrantes del Grupo Minorista solo Carpentier y Eugenio Florit participaron, años más tarde, periódicamente, entre los colaboradores de la revista Orígenes fundada por Lezama Lima y Rodríguez Feo y que fue el misal del Grupo Orígenes.

Años después, tras la publicación de La música en Cuba, Carpentier apuntala su ruptura con el ideario minorista y la estrechez de miras de lo regionalista y lo folklórico cómo única vía de acceso al arjé americano con la publicación de Tristán e Isolda en Tierra Firme (1949). Dicho ensayo fue publicado originariamente en la revista venezolana Cultura Universitaria del periódico $E l$ Nacional el 4 de setiembre de 1949, y, a lo largo del mismo año, en la Imprenta Nacional de Caracas, acompañado oportunamente del subtítulo "reflexiones al margen de una representación wagneriana". El célebre prólogo a El reino de este mundo es, de hecho, la reelaboración especular de este ensayo.

En Tristán e Isolda en Tierra Firme, Carpentier se afana en sintetizar las leyes que habrán de gobernar su producción novelística y la de algunos escritores del boom. A resultas de la problemática confluencia entre lo nacional y lo supranacional, el autor trata de articular un cosmopolitismo permeable al influjo europeo, sin claudicar de los asideros que el folklorismo y el regionalismo imponen al escritor americano. La oscilante tensión entre polis y cosmópolis, asumida como condición de posibilidad del ser americano, se resuelve en una rearticulación de la Weltliteratur, en un itinerario que eleva de lo local a lo universal y que afinca lo americano, como categoría resultante de lo múltiple, en el ancho espacio del 
mundo: "ya se va cobrando conciencia" anuncia el autor, "de que lo universal se alcanza mucho mejor cuando se sigue el camino señalado por Don Miguel de Unamuno" (Carpentier 1949: 11), esto es, de dentro a fuera; de lo efímero a lo perpetuo, de lo local a lo universal. La ópera wagneriana Tristán e Isolda será solo el pretexto para alumbrar el camino a una desprovincialización de la novela americana y a una depuración de temas y recursos contingentes: "de la balcanización a la integración" como dirá Pogolotti (2007: 92). En las páginas finales de La música en Cuba dicha tesis ya había aparecido anunciada:

Los adversarios de las tendencias nacionalistas que prevalecen hoy en Brasil, en México, y, con mayo ro menor fuerza, en casi todas las naciones del Nuevo Mundo, se valen a menudo de un argumento polémico que es, poco más o menos, el siguiente: inspirarse en música de negros, de indios, de hombres primitivos, no es un progreso; desligarse de la gran tradición artística europea, sustituyendo las disciplinas de la cultura occidental por el culto del vodú, del juego ñáñigo, del batuque, del candombe, equivale a renegar de las raíces más nobles de nuestra idiosincrasia, colocando un tambor en lugar del clavicordio (Carpentier, 2004: 326).

Los ensayos musicales de Carpentier catalizan el proceso de desfolklorización de la narrativa autoral. El texto La música en Cuba (1946) opera como relectura de la poética minorista $\mathrm{y}$, en $\mathrm{su}$ análisis prolijo de los periodos constitutivos del criollismo musical (que podrían ubicarse en un vector horizontal), el autor pudo reconceptualizar -reconquistar- la noción transculturación y el ideal martiano de la conciliación entre etnias. Carpentier desacraliza el legado afrocubano y lo reubica en el seno de un discurso preeminentemente blanco, pero dependiente de ese acento diferenciador que el negro otorga, y que lo convierte en el agente esencial de la transmutación. El ensayo Tristán e Isolda en Tierra Firme (1949), por otra parte, despliega una propuesta de mundialización de lo americano que el autor había sugerido sutilmente en los capítulos señeros de La música en Cuba. En un vector vertical, la vía de la literatura es de abajo a arriba, de lo local a lo universal, en un camino de ida y vuelta que realza los rasgos ecuménicos de unos elementos que, vagamente compilados en listados y operando como telón de fondo de la novela regionalista, resultaban fundamentales en aras de expresar la esencia de América. La tendencia afrocubanista, dirá el autor, "solo llegó a lo superficial y periférico, al "negro bajo palmeras ebrias de sol"” (2004: 307). Los dos ensayos son hermanos, se entrelazan dialécticamente: uno es el violín; el otro, el arco. Con El reino de este mundo (1949) se inicia el nuevo ciclo de la escritura del autor, el del Carpentier que todos hemos conocido. Su musicología fue el germen del cambio.

\section{A modo de síntesis}

Decía, en los apartados anteriores, que la ensayística musicológica de Carpentier se subdivide en cuatro textos cenitales, a saber: el ensayo madre, La música en Cuba (1946), el ensayo hermano, Tristán e Isolda en Tierra Firme (1949) -que 
contrapuntea al madre-, y, finalmente, Del folklorismo musical (1964) y América Latina en la confluencia de coordenadas históricas y su repercusión en la música (1975), que sintetizan la musicología del autor y la matizan a lo largo de su itinerario productivo sin introducir cambios sustanciales.

La musicología de Carpentier desplegará, a través de dichos ensayos, cuatro reflexiones rectoras que tomarán forma, después, en su programa narrativo: 1) Reconceptualización de la noción transculturación como categoría indiciaria de un proceso en el que la cultura subalterna es asimilada y reubicada en el seno del discurso hegemónico europeo. Relativización, por tanto, en la línea crítica de Cornejo Polar, del carácter contrahegemónico que Ortiz había otorgado al concepto transculturación. 2) Consolidación y desacralización del elemento afrocubano como marca diferenciadora del hecho sonoro. 3) Desarrollo de una tesis cosmopolita en Tristán e Isolda en Tierra Firme (y, más tarde, en Del folklorismo musical) que catalice el proceso de desbalcanización de la música cubana y que resuelva la tensa interacción entre lo local y lo universal. 4) Desarticulación de la dicotomía culto/popular en tanto que la amalgama musical caribeña es fruto de un proceso dialéctico, y asimétrico, en el que la melos, correlato de lo culto, permuta en su contacto con el folklore afrocubano.

Dichas tesis, como argüía, se materializan en la novelística carpenteriana según cuatro itinerarios rectores que recodifican temas, espacios y personajes: 1) Desarrollo de una poética mestiza -en la línea de Fuentes, Arguedas, Asturias, Picón Salas, o, más tarde, García Márquez- que no se vea acantonada por los localismos y que reactive el acervo cultural europeo como categoría definitoria de lo americano, lo que corrobora el paulatino distanciamiento del autor con el minorismo ortodoxo. 2) Paulatino blanqueamiento y desafricanización de la prosa autoral según se sustrae de la impronta minorista. De iÉcue-Yamba-Ó! a El reino de este mundo, tal proceso comenzó a incubar en el ciclo transicional que he conferido al ensayismo musicológico del autor. A nivel narrativo, los personajes negros son reemplazados por personajes blancos y mestizos; los espacios se ramifican y pasan de abarcar el campo cubano, área exclusiva de iÉcue-Yamba-Ó!, a las grandes urbes europeas y americanas en novelas como El reino de este mundo, El siglo de las luces, Concierto barroco o La consagración de la primavera, o pasan a desplegar la interacción selva-ciudad, en textos como Los pasos perdidos, como figuración del antagonismo civilización-barbarie. Los rasgos tipificados como folklóricos dejan, así, de obstaculizar recursos y elementos de interés para el autor. 3) Desarrollo de la tesis cosmopolita de Tristán e Isolda en Tierra Firme con la oportuna desacralización del acervo cultural afrocubano y su integración en un espacio dialógico que confronta lo europeo y lo africano como estadio de materialización de lo americano. 4) Dosificación y relectura de los elementos procedentes de la cultura subalterna, con la consiguiente pérdida de su carácter protagónico y su reubicación funcional en el seno de un discurso mestizo.

El estatus ontológico del ser americano es, definitivamente, reconceptualizado en los ensayos musicales de Carpentier, que resuelven de modo parcial la problematicidad inherente de nociones como transculturación o mestizaje, con la asunción del carácter hegemónico que dichos conceptos entrañan. La labor ensayística del autor establece los fundamentos estructuradores de su poética desde El reino de este mundo en adelante y produce un amplio espectro de cambios con 
respecto de ¡Écue-Yamba-Ó! que operan en tanto recategorización de los protagonistas, en la confección dialógica de los espacios, en la relectura y aprovechamiento de elementos culturalmente periféricos y en la adecuación del pensamiento europeo (Spengler, Schopenhauer, Nietzsche, Sartre, etc.) al contexto americano, entre otros.

El desarrollo de esta intuición merecería varios artículos aparte para ratificar cómo la expresión del autor y sus temáticas no son sino una variante especular de su reflexión musicológica. El propósito de este artículo era, únicamente, alumbrar las líneas investigativas que cristalizan en La música en Cuba para constatar su influjo en la narrativa autoral. No es este, pues, un itinerario cerrado, sino una propuesta innovadora, tentativa y abierta, susceptible de ser ampliada, y que concede una relevancia especial a unos textos escasamente atendidos, cuyo examen podría optimizar la exégesis de la narrativa del autor desde una perspectiva multidisciplinar músico-literaria.

\section{Referencias bibliográficas}

Acosta, Leonardo. Música y épica en la novela de Alejo Carpentier. La Habana: Editorial Letras Cubanas, 1981.

Adorno, Teodor, "El ensayo como forma", en Notas de literatura. Barcelona: Ariel, 1962.

Cancio, Wilfredo. Crónicas de la impaciencia. El periodismo de Alejo Carpentier. Madrid: Editorial Colibrí, 2010.

Carpentier, Alejo. Tristán e Isolda en Tierra Firme. Harvard: Poetique Musical/ Harvard University Press, 1949.

- El reino de este mundo. La Habana: Bolsilibros Unión, 1964.

- Tientos y diferencias. La Habana: Contemporáneos, 1974.

-Bajo el signo de Cibeles. Madrid: Editorial Nuestra Cultura, 1979.

- Razón de ser. La Habana: Editorial Letras Cubanas, 1980.

- La novela latinoamericana en vísperas de un nuevo siglo y otros ensayos. Madrid: Siglo XXI Editores, 1981.

- La ciudad de las columnas. Barcelona: Bruguera, 1985.

- Temas de la lira y del bongo. La Habana: Letras Cubanas, 1994.

- El amor a la ciudad. Madrid: Alfaguara, 1996.

—Visión de América. Barcelona: Seix Barral, 1999.

- La música en Cuba. México: FCE, 2004.

- La consagración de la primavera. Madrid: Alianza Editorial, 2004.

-Los pasos perdidos. Madrid: Akal, 2009.

-Concierto barroco. Madrid: Alianza Editorial, 2009.

- El reino de este mundo. Madrid: Alianza Editorial, 2011.

Castellanos, Jorge e Isabel Castellanos. Cultura afrocubana. 1. El negro en Cuba 19421844. Miami: Ediciones Universal, 1988.

Chao, Ramón. Conversaciones con Alejo Carpentier. Madrid: Alianza Editorial, 1998.

Cristóbal, Armando. Del Acoso a la Consagración. La Cuba del siglo XX en la novelística de Alejo Carpentier. Madrid: Visionnet, 2003.

Leante, César, "Confesiones sencillas de un escritor barroco", en Helmy F. Giacoman, Helmy F. Homenaje a Alejo Carpentier. Variaciones interpretativas en torno a su obra. New York: Las Américas Publishing, 1970, pp. 11-31. 
Márquez Rodríguez, Alexis. La obra narrativa de Alejo Carpentier. Caracas: Ediciones de la Biblioteca/ Universidad Central de Venezuela, 1970.

Mocega González, Esther P. La narrativa de Alejo Carpentier: el concepto del tiempo como tema fundamental (ensayo de interpretación y análisis). Madrid: Eliseo Torres \& Sons, 1975.

Müller Bergh, Klaus, "Oficio de tinieblas, un cuento escasamente conocido", en Klaus Müller Bergh. Asedios a Carpentier: once ensayos críticos sobre el novelista cubano. Santiago de Chile, Editorial Universitaria, 1972, pp. 53-62.

Ortiz, Fernando. La música afrocubana. Madrid: Biblioteca Júcar, 1974.

- Contrapunteo cubano del tabaco y el azúcar. Madrid: Cátedra, 2002.

Pogolotti, Graziella. El ojo de Alejo. La Habana: Ediciones Unión, 2007.

Cornejo Polar, Antonio, "Mestizaje, transculturación, heterogeneidad", Revista de Crítica Literaria Latinoamericana, 40, 1994, pp. 363-374.

Velayos Zurdo, Óscar. El diálogo con la historia de Alejo Carpentier. Barcelona: Península, 1985.

Villanueva, Carlos, "Y el Sonido se hizo Palabra: escuchando fragmentos de Alejo Carpentier", Quintana: revista de estudios do Departamento de Historia da Arte, 4, 2005, pp. 135-154. 